\title{
Tectono-Sedimentary Evolution of the Offshore Hydrocarbon Exploration Block 5, East Africa: Implication for Hydrocarbon Generation and Migration
}

\author{
Ezekiel J. Seni' ${ }^{1}$, Gabriel D. Mulibo ${ }^{1}{ }^{*}$, Giovanni Bertotti ${ }^{2}$ \\ ${ }^{1}$ Department of Geology, University of Dar es Salaam, Dar es Salaam, Tanzania \\ ${ }^{2}$ Department of Geoscience and Civil engineering, Deft University of Technology, Delft, The Netherland \\ Email: *gmbelwa@yahoo.com
}

How to cite this paper: Seni, E.J., Mulibo, G.D. and Bertotti, G. (2018) Tectono-Sedimentary Evolution of the Offshore Hydrocarbon Exploration Block 5, East Africa: Implication for Hydrocarbon Generation and Migration. Open Journal of Geology, 8 , 819-840.

https://doi.org/10.4236/ojg.2018.88048

Received: June 8, 2018

Accepted: August 1, 2018

Published: August 3, 2018

Copyright $\odot 2018$ by authors and Scientific Research Publishing Inc. This work is licensed under the Creative Commons Attribution International License (CC BY 4.0).

http://creativecommons.org/licenses/by/4.0/

\section{(c) (i) Open Access}

\begin{abstract}
Sedimentary deposits in Block 5, offshore Tanzania basin have been imaged using two-dimensional (2D) seismic data. The seismic data and well data reveal four tectonic units representing different tectonic events in relation to structural styles, sedimentation and hydrocarbon potential evolved in Block 5 . Results show that during Early to Late Jurassic, Block 5 was affected by the break-up of Gondwana and the drifting of Madagascar as evidenced by patterns of sediments and structural features. The chaotic and discontinuous reflectors are characteristics features on the sediments pattern indicating a possible transitional setting following the breakup of Gondwana. From the Late Cretaceous, Block 5 sits in more stable subsiding sag as the consequence of the high thermal subsidence. The period displayed continuous parallel reflectors with few markable faults. This was followed by the late post rift sedimentation that occurred after Middle Eocene Unconformity characterized by high wavy and sub parallel reflectors. The evolution of Block 5 through major tectonic events reveals a more complete petroleum system towards the south. Thus, Block 5 responded in both space and time to a complex interplay between tectonics and sedimentation. This indicates that structural styles and associated features are potential control for hydrocarbon generation and migration.
\end{abstract}

\section{Keywords}

Offshore Tanzania basin, Block 5, Tectonics, Sedimentation, Hydrocarbon, East Africa 


\section{Introduction}

The exploration Block 5 is found within the known Mafia Deep Offshore Basin formed as a product of Gondwana breakup [1] (Figure 1). The offshore exploration Blocks are located in East African Passive Continental Margin setting [2]. Other worldwide known basins, which are in passive margin, are Santos (Brazil) in South Atlantic Continental Margin and Gulf of Mexico [3] [4]. Within the East African margin there have been major gas discoveries (more than $200 \mathrm{Tcf}$ (trillion cubic feet) recoverable gas reserves) particularly in the Rovuma Delta and Mafia Basin. The Rovuma Delta traverses along the Tanzania-Mozambique border where recent discoveries have attracted exploration activities along this margin. Offshore exploration Blocks within the Mafia Deep Basin of Tanzania encompass Blocks 1 to 12, which are bordered to the south by Rovuma Delta, the Mafia Island to the north and by the Davie Ridge transform to the east (Figure 1). These offshore deep water Blocks are categorized into two groups namely North Offshore Blocks (NOBs) that include Blocks 5 to 12 and the South Offshore Blocks (SOBs) consisting of Blocks 1 to 4.

Most of the recent hydrocarbon discoveries occur in the Southern Mafia Deep Offshore Basin, where BG has estimated more than $15 \mathrm{Tcf}$ of gas in Blocks 1, 3

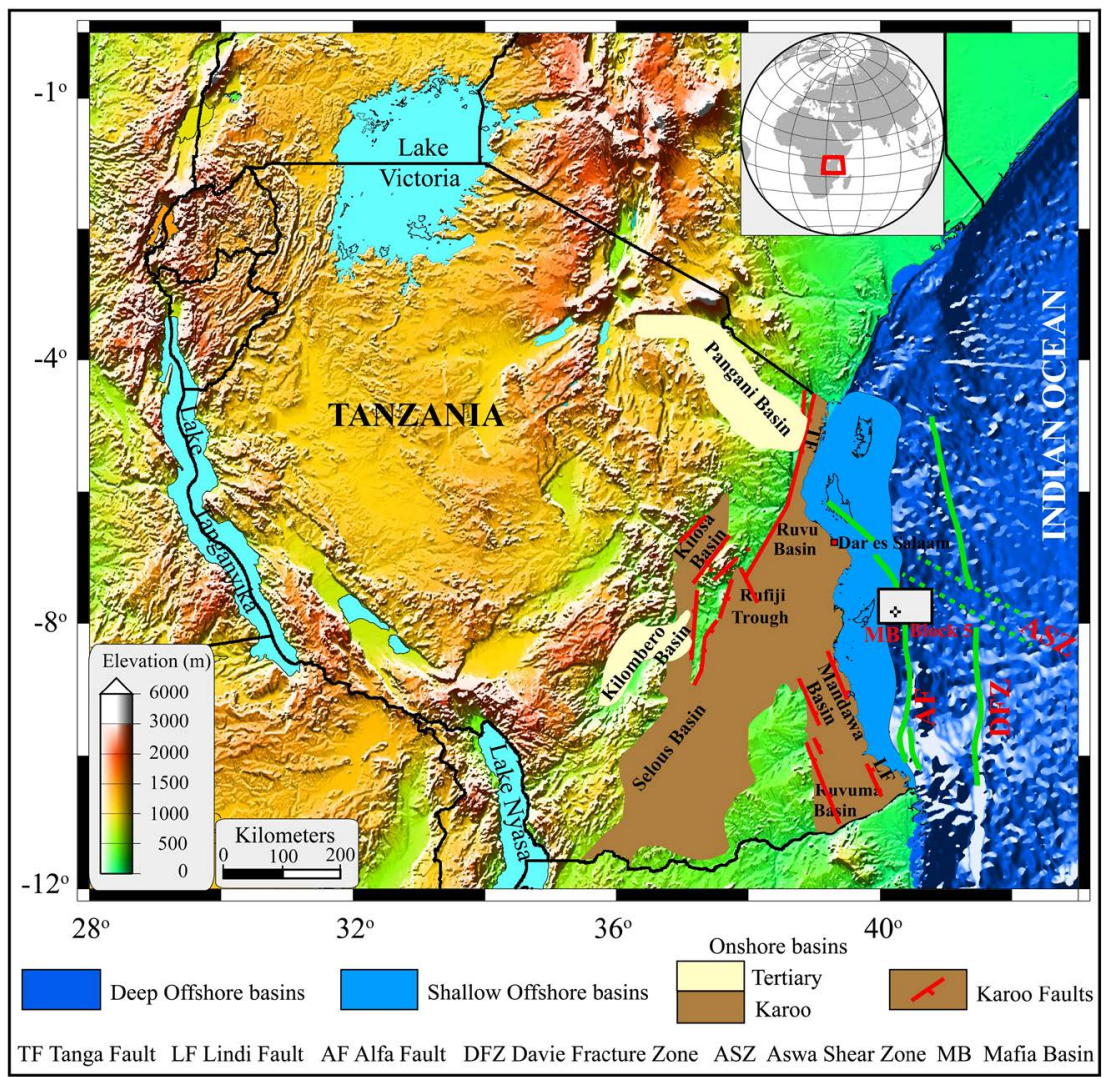

Figure 1. A topographic map of Tanzania (ETOPO1; [14]) showing the Tanzania coastal basin (onshore and offshore basins) and the present-day structure of the offshore Tanzania named as Davie Fracture Zone, Alpha Fault and Aswa Shear lineation (modified after [49]). The figure also shows the location of Block 5 . 
and 4, and 22 Tcf of gas has been estimated by Statoil and ExxonMobil in Block 2 [5] [6]. Several plays of Late Cretaceous to Oligocene channel sand bodies and turbidities have been documented and are hosted in stratigraphic and structural traps within deep marine shale [2] [7].

Despite much gas has been discovered in the Southern Mafia Deep Offshore Basin, the North Offshore Blocks (NOBs), which is believed to have a similar geology to the Mafia Basin and where this study lies, have less hydrocarbon discoveries. There has been a few observed oil seeps on Pemba trough [8] and Mafia Island as well as some dry reservoir sandstones wells within deep-water [9]. Although offshore part of Tanzania is well endorsed with potential hydrocarbon system, the tectono-sedimentary evolution of exploration Block 5 is little documented or unpublished. The most crucial question is about the evolution, sedimentation and the structural style in relation to petroleum potential of the offshore particularly in exploration Block 5 .

Based on the emerging offshore exploration interest, the link between the lacks of hydrocarbon in NOBs particularly Block 5 and its tectono-sedimentary settings has been investigated/reappraised in this study. Enlightening the possible petroleum system and understanding evolution process in Block 5 are vital in further defining future exploration target in the NOBs. The 2D seismic reflection dataset and one well data have been used to review the evolution and tectonic style associated with the formation and sedimentation of offshore exploration Block 5.

\section{Geology and Geotectonic Setting}

\subsection{Regional Geology and Geotectonic Setting}

The depositional history of the coastal basin and offshore Tanzania is strongly influenced by the breakup of Gondwana in Middle Jurassic approximately 167 - 170 $\mathrm{Ma}$ and ended in Early Cretaceous (118 Ma) [2] [10]-[15] Gondwana was split into western (South America and Africa) and eastern (Antarctica, India, Madagascar and Australia) blocks [13]. Madagascar (and other East-Gondwana terranes) successfully drifted away from Tanzania, Kenya and Somalia during the Late Jurassic prior to dextral strike-slip movement southwards along the Davie Ridge transform zone [16]. The separation of Madagascar away from Tanzania initiated the development of a passive continental margin of Tanzanian [17].

The drifting of Madagascar southward along the Davie fracture zone is not clearly defined, which is thought to commence as early as 183 - $177 \mathrm{Ma}$ [18] [19] but may have been as late as Middle Jurassic (165 Ma) [20], and reached the present location in Early Cretaceous approximately $118 \mathrm{Ma}$ [2] [10]. The opening of the Somali basin and the invasion of the Indian Ocean explain the increase of block separation between Madagascar and Tanzania [14] [21]. From Cretaceous, offshore Tanzania was controlled by thermal subsidence leading to much development of a passive margin and deepening of the ocean. This was further followed by regional East Africa Rift System (EARS) predicted to influence later 
structural reactivation and local deformation recognized in both offshore and onshore [13] [22] [23].

\subsection{Geological Setting of the Offshore Tanzania}

From Onshore, the major structural trend includes NNE-SSW (Tanga) and the Lindi NNW-SSE [14] [24] [25]. As for the offshore structural trends, the faults are commonly post-Karoo. These post rift faults are considered to be reactivation of older faults since they display a similar trend [14]. The exploration Block 5 is bounded by three tectonic structures named as Eastern Davie Fracture Zone, Alpha fault and Aswa Shear Zone, which form major structures east of Mafia Deep Basin [14] (Figure 1).

The Davie fracture (NW-SE trending structure) is a continental oceanic boundary running in N-S direction [14] and conforms to strike slip movement that drifted Madagascar, southward [26]. The fracture is considered to be equivalent to shear strike slip [27], defined as a basement high dipping gentle in east and steeply in west [26]. Most of the hydrocarbon discoveries are hosted in the western part of the Davie Fracture zone and Alpha Fault in Tanzania and Mozambique [27].

Different possibilities of the offshore source of sediments have been suggested and one possibility has been explained by McDonough et al. [28] as originated from Rufiji and Ruvuma deltas and transported by down slope turbidite current as in Block 2 about $80 \mathrm{~km}$ from the margin. Another possibility is that the offshore sediments could have derived from the coast parallel surface currents [29]. In recent times several currents have been described being active along the coastal Tanzania [29] [30].

\subsection{Interplay between Tectonic and Sedimentation}

The characteristics of any basin fill are controlled by tectonic events, which initiate the accommodation and later trigger sediment filling as sourced from the uplifted and eroded blocks [31] [32]. Basement subsidence, tectonic transfer zones and palaeomorphological features plays vital role in controlling the accommodation space and sedimentary system [32]. The interpaly between the accomodatio $\mathrm{n}$ space, amount of sediments and geometry of the basin have been studied by different authors (e.g., [33] [34] [35] [36] [37]). Gawthorpe [35] and Morley [36] mentioned on the importance of early fault, which propagates, grows and later successful links as major tectonic control on the basin architecture. The early filling characteristic and accommodation is a matter of linkage between rift faults.

The initial rifting is indicated by mechanical subsidence [2] [31] and the Break Up Unconformity (BUC) is indicated by transition from mechanical to drifting. The onshore Coastal basins and BUC have been recognize and mapped to occur during Middle Jurassic period [1] [14]. The post rifting or drifting phase is controlled by thermal cooling where high subsidence creates the depocenters or sag. 
The filling sediments especially in post rift phase are functions of available source and depositional place. Tectonic influences the distribution of sedimentary pattern where it forms the major control of depositional environment and their available space. The mode of sedimentation consists of continental shelf, transitional to full marine depositional environment.

\section{Data and Methods}

\subsection{D Seismic Data}

The primary regional data set is a $2 \mathrm{D}$ seismic reflection that was collected by FUGRO for Petrobras across the study area in 2004-2006 (Figure 2; Petrobras, 2012-upublished geological report). The data consist of six lines with two strike lines (EO_0073 and EO_0092) and four dip lines (EO_0065, EO_0066, EO_0068 and EO_0072). The 8-km wide, $12.5-\mathrm{km}$ long survey area covered the region defining the most edge boundaries of Block 5 (Figure 2).

\subsection{Well Data}

The study used well data from the well called Mchongoma, which penetrated to a total depth of $4833 \mathrm{~m}$ (Petrobras, 2012-unpublished geological report). Information such as well header, wireline logs, checkshot and biostratigraphy information were provided as part of the well data. The well header provided the coordinates of the well and the trajectory path details. The wire line logs measurements started at $2200 \mathrm{~m}$ down to $4833 \mathrm{~m}$. Some of the logs such as density logs were available only from $3420.20 \mathrm{~m}$ to $4833 \mathrm{~m}$ depth due to drilling and logging problem. The sonic logs were used for calibration [38] [39]. Checkshot data were taken from survey report and were used as a benchmark for establishing time depth relationship between the seismic section in time domain and the

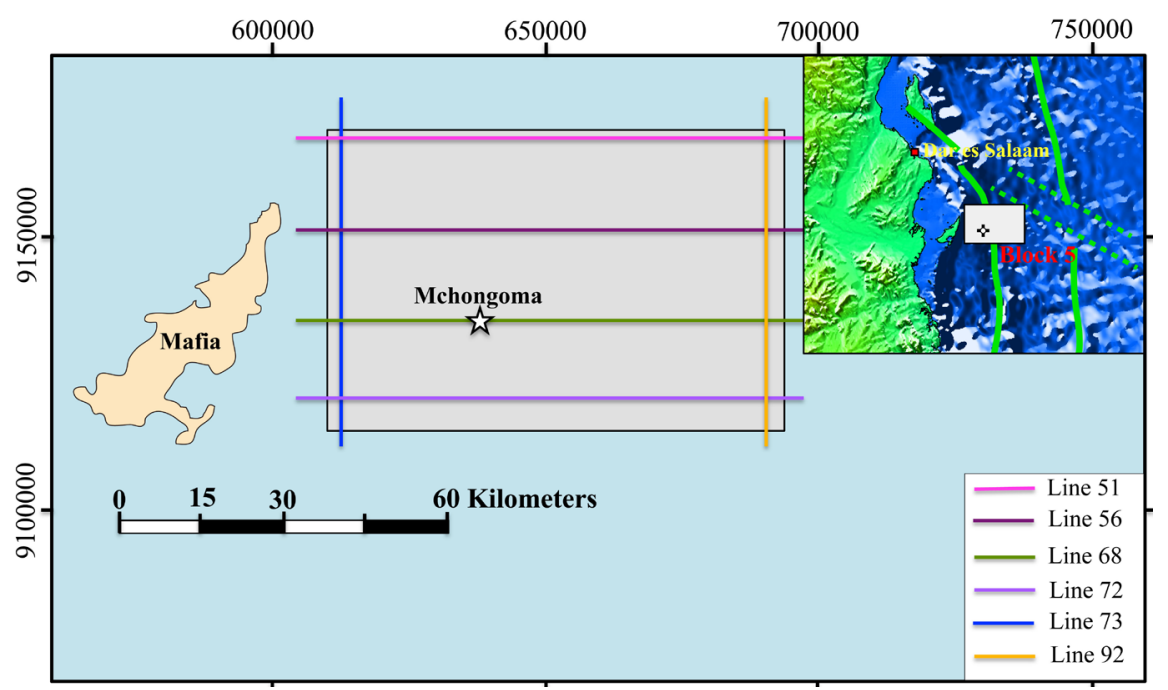

Figure 2. Location of Block 5 with six 2D seismic lines. The seismic lines are EO_0073 and EO_0092 strike and EO_0051, EO_0056, EO_0068 and EO_0072 dip lines. White star shows the location of Mchongoma well in line EO_0068. 
well in depth domain. From the well downhole survey a noticeable maximum deviation of about $5 \mathrm{~m}$ were recorded from the coordinate computation. This deviation was taken as minimum and the overall trajectory path was assumed to be vertical well.

\subsection{Seismic Method}

The basic processing through pre-stack time migration was performed using $\mathrm{Pe}$ trel software 2014. Calibration was done using sonic data and corrected for drift to at least acceptable drift value of about $7 \mathrm{~m}$. Synthetic seismograms were generated using sinusoidal sonic density from calibrated sonic log to achieve a comparable seismic to well tie (Figure 3). It was not possible to use density in generating seismograms since the density log measurements were missing in some well depth intervals attributed by drilling and technical issues (Petrobras, 2012-unpublished geological report).

Interpretation of seismic data involved picking of faults and horizons where the faults are picked to delineate the trend of geological structure of the area and understand the structural style of the area while horizons tell the continuity of strata, depositional and stratigraphy (Figure 4). From the well to seismic tie (Figure 4), four (4) top seismic traces which were later labeled A7 to A4 horizons tied closely to four (4) well tops and were used as guidance during interpretation. The four tops are Sea Bottom (A7), Middle Eocene (A6), Lower Eocene (A5) and Lower Coniacian (A4) respectively (Figure 4). In addition three

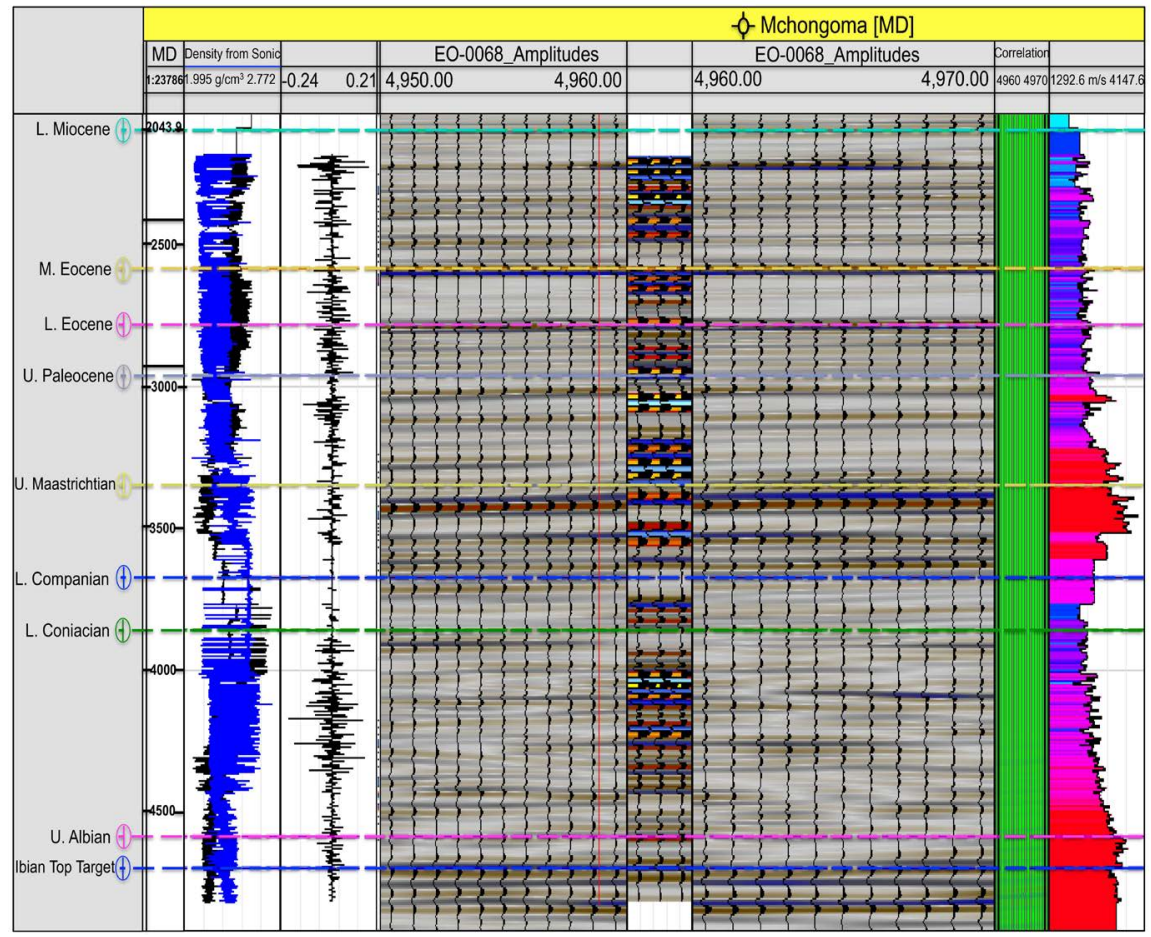

Figure 3. Well to seismic tie result for Mchongoma well and Section EO_0068 with Formation Tops. 


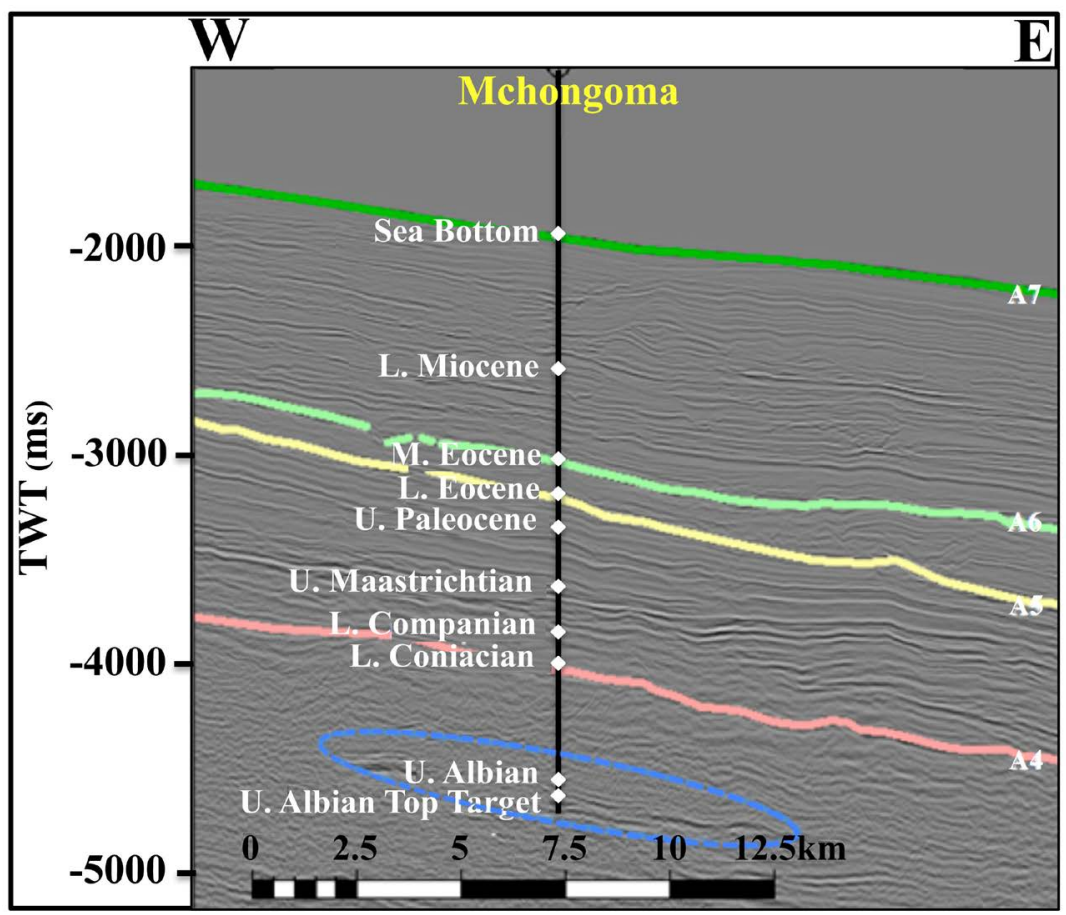

Figure 4. Section line EO_0068 tied to Mchongoma well showing horizons A7 to A4 picked near formation top that define the tops of the seismic sequences. The well targeted the Albian channel sand (light blue doted circle).

horizons (A1 to A3) were traced and picked below the well depth. These three horizons were picked based on continuous, high amplitude and well-traced reflectors.

\section{Results and Interpretation}

\subsection{Tectono-Stratigraphic Units and Structural Features of Block 5}

From the seismic data, four tectono-stratigraphic units (Units 1 - 4) and eight faults have been identifies bounded by region unconformities (key horizons) with similar or related seismic characteristics. Units 3 and 4 were supplemented with well formation top tied close to A4 through A7 horizons (Figure 3). Horizons A3 and A4 were untraced in some portion of the sections due to discontinuity nature of the reflectors and wide space seismic line used in the study, which pose correlation uncertainties.

\subsubsection{Seismic Unit 4 (Middle Eocene to Present)}

The unit is bounded by A6 and A7 horizons and forms the later post rift phase with uniform, parallel and continuous reflection on both sides of the fault F4 (Figure 5(a)). Common zones of internal disturbed reflections related to high sediments input have been recorded (Figure $5(\mathrm{~b})$ ). The most continuous horizon A6 can be traced over the whole block. Above horizon A6 there are transparent zones associated with depositional changes and is also characterized by the presence of disturbed discontinuous reflectors, concave channels and slumps 

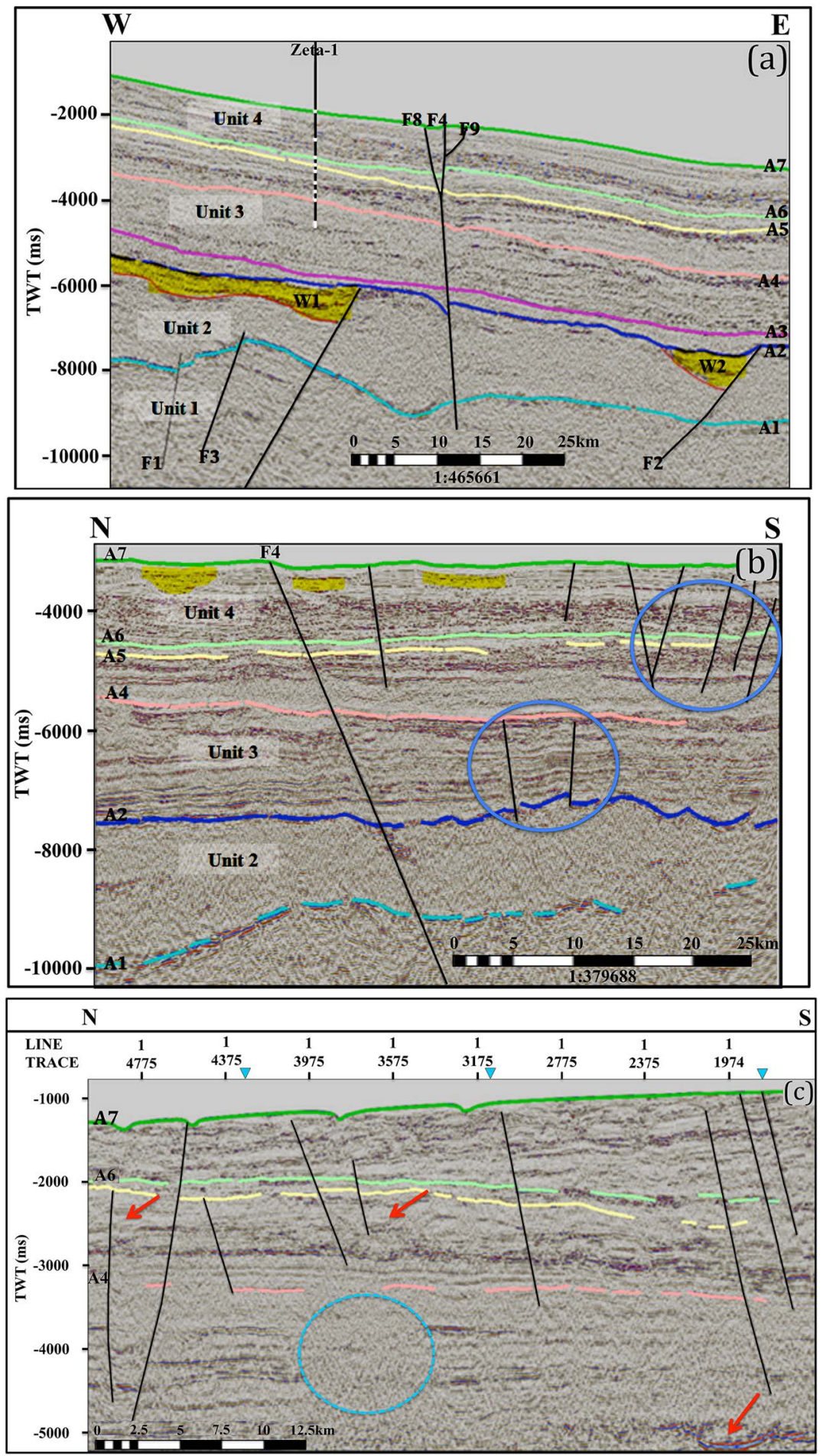

Figure 5. (a) Interpreted seismic section line EO_0068 tied to Zeta-1 well with fault F4 showing flower features between A5 and A7 horizons. Note the early syn-rift wedges W1 and W2, tilted and eroded horizon A1; (b) Interpreted strike seismic section EO_0092 indicating south thickening of sediments between A4 and A7. On the other side the sediments between A2 and A4 are thickening towards the north (black line indicates faults, channels are colored yellow and blue circle indicates local deformation); (c) Section EO_0073 showing deformation from the seabed A7 and relative deformed layer above A4 with channels like features (red arrows) and wipe out zone (blue circle). 
(Figure 5(b)). Between horizons A6 and A7 deposited sediments show relatively eastern thickening (Figure 5(a)).

The unit is crossed throughout by the major fault structure F4, with small young conjugate faults F8 and F9 occurring adjacent to it. These faults display a structure resembling to the negative flower (Figure 5(a)).

\subsubsection{Seismic Unit 3 (Early Cretaceous to Middle Eocene)}

The unit is formed by the early post rift sediments between A2 and A6 horizons and is characterized by the absence of tilted reflectors (Figure 6(a)). It extends from the west and gradually increases thickness towards the eastern part, filling the depocenter and minor fault activities. The features include parallel-to-parallel reflections mostly dominating the eastern part of the fault F4 where horizon A2 is sagging to the east due to thick sediment deposited on top of it (Figure 6(a)). Horizon A4 divides Unit 3 into upper and lower subunits while A5 further subdivides the upper subunit. The most top continuous transparent zone is between the A6 and A5 (Figure 6(a)).

In the upper subunit overlaying A4 is a transparent zone observed only to the east. The subunit thickens towards the east topped by the presence of high sub parallel reflectors, which are down lapping to A4 towards the west (Figure 6(a)). The upper subunit is related to the change of depositional pattern (Figure 6(a)). Between A4 and A6, multiple cycle of sediments were deposited (Figure 6(b)) which was also confirmed in seismic, well logging data and core sample to consists of cycle of fine to medium massive sandstone channels deposited in fine laminated mudstone (Petrobrass, 2012). The sand fills most of the channels lobe forming.

The lower subunit is between A2 and A4 horizons with medium intensity and denser parallel reflectors increasing downward to A2 (See Figure 6(a)). More defined reflectors are seen east of major fault $\mathrm{F} 4$. The unit fills the deeper post rift depocenter, which occur mostly in the eastern part. Further to the eastern part, reflectors in the lower subunit are affected by the geometry of buried structures. The structures affected the sedimentation patterns as indicated by sediments overlying it (Figure 6(b) and Figure 6(c)). The reflectors in the lower subunit show closed channels features in the western part and slumps (Figure 6(c)) close to the top of A4. The lower subunit represents the wide accumulation of possible marine argillaceous mud with fine sand lenses related to transgression occurred in the early Cretaceous (Petrobras, 2013-upublished report) as the basin was deepening to the east. These sediments are represented in the eastern part of the fault F4, by eastern high amplitude parallel reflectors between A2 and A4 with transparent sand zones (Figure 6(b)).

The major structural feature found in this unit is Fault F4, which is extended from Unit 1. The unit represents a period of quite fault activities with minor evidence of deformation controlled by sedimentation. In the upper portion noticeable structure reactivation is predicted which is evidenced by few anticlines and normal faults. 


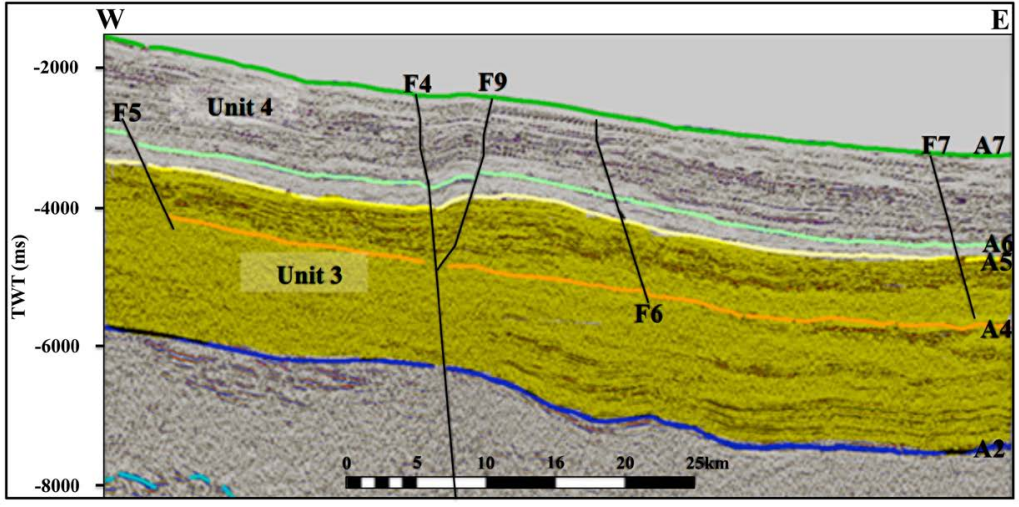

(a)

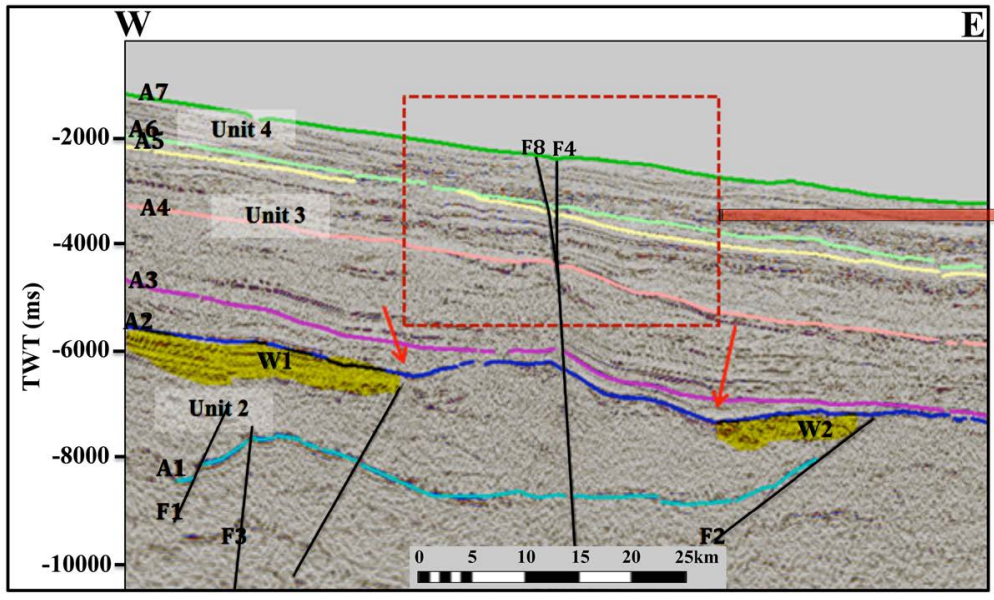

(b)

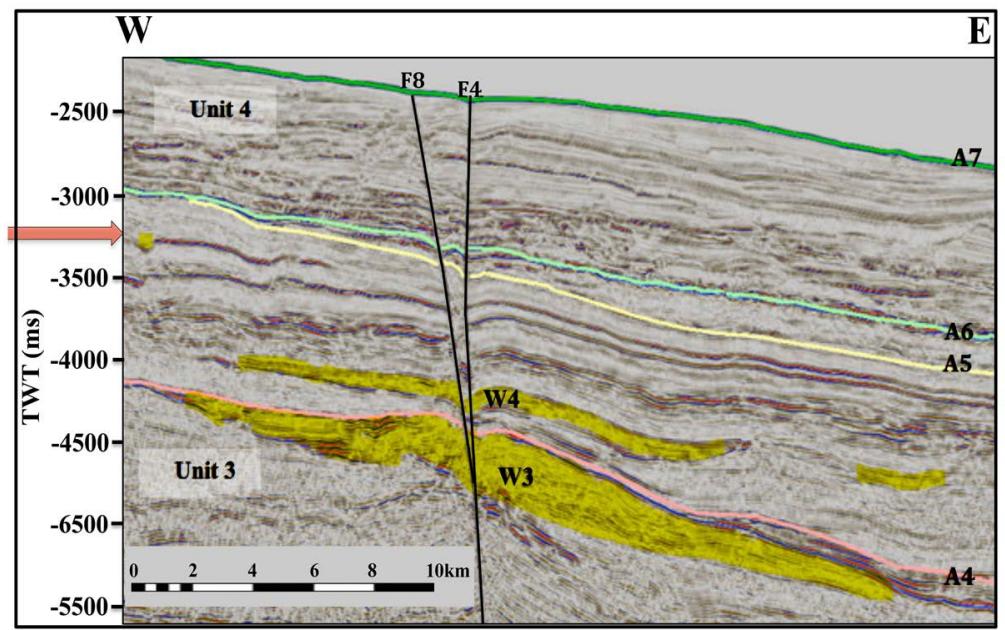

(c)

Figure 6. (a) Interpreted seismic section EO_0056 with reactivated fault F9 forming an inversion feature indicated by yellowish thickening of sediments between A2 and A6 horizons; (b) Interpreted seismic section EO_0072 with uplifted horizon A1 west of fault F4. Note on the change of reflection pattern highlighted in yellow in W1 and W2. The red arrow shows possible post-rift depression above A2 and fault F4 define the syn-depositional wedge W2; (c) Insert from section EO_0072 with unit 3 showing sand channels W3 and W4 associated with huge volume of sediments deposited and being reshaped by fault F4. 


\subsubsection{Seismic Unit 2 (Middle Jurassic to Early Cretaceous)}

The unit is bounded by $\mathrm{A} 1$ and $\mathrm{A} 2$ horizons representing bottom and top boundaries respectively. The horizon A2 can be traced over the whole area forming the top reference horizon picked for Unit 2 (Figure 7). The top of the unit has eastward dipping reflectors on both sides of the fault $\mathrm{F} 4$ while the lower part above A1 shows uniform reflections, which dominate the whole unit. Within upper part of the unit, wedge W2 is seen with more reflectors in the eastern part and less in the western part (Figure 7). The wedge W1 as compared to W2 displays more developed parallel continuous reflectors in the west as moving from north to south (See Figure 6(b)).

In the eastern side of fault F4, wedge W2 displays chaotic reflectors dragged by existing subsurface feature at A2 (Figure 7) and seems to diminish in the north south direction. In the western side of Unit 2 there is a noticeable change in reflection pattern between the lower and the top part close to A2. The top has uniform parallel reflections while the lower has tilted discontinuous reflection (Figure 6(b) and Figure 7) conforming to early tectonic events dominating the area.

Limited structures affect Unit 2 and the most dominant structures in the unit are faults F1, F2 and F3 (Figure 5(a) and Figure 7). These faults have much influence on the geometry and distribution of early deposited sediments. They form part of early basement fault, since they are rooted to what is inferred to be the basement. The fault F4 is also projected to be rooting from the basement but show dissimilar feature of a typical normal fault like F1 and F2.

\subsubsection{Seismic Unit 1 (Top Early Jurassic)}

The unit is defined by top horizon A1 with no clear lower boundary traced. The most dominant features are discontinuous, chaotic reflectors with low frequency and amplitude. The horizon A1 is uplifted in the western side and relatively flat in the eastern side (Figures 5(a), Figure 6(b) and Figure 7). In a closed look, the reflectors are chaotic and show discontinuity. No well has penetrated the early Jurassic offshore Tanzania, which makes difficult to date the unit.

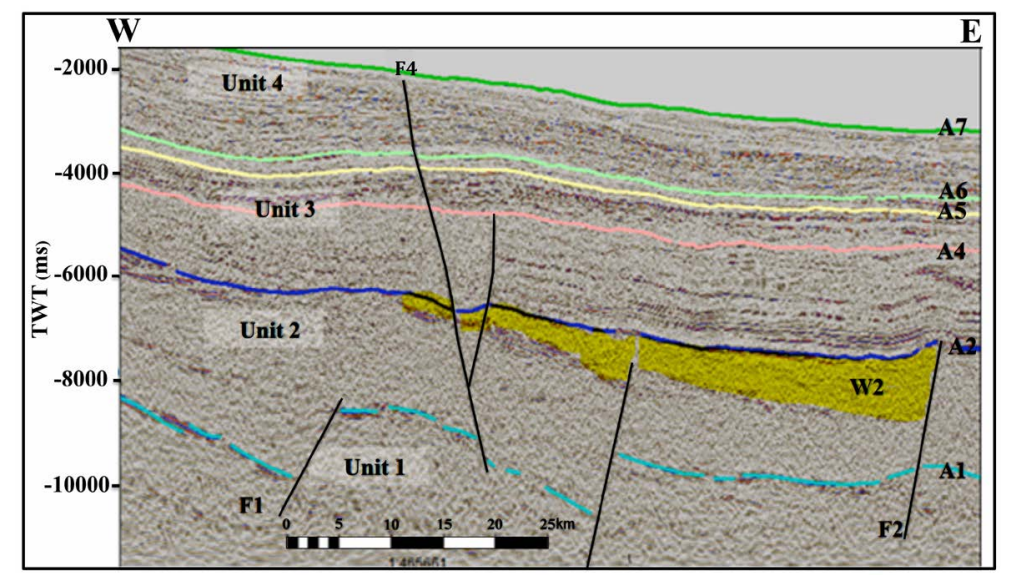

Figure 7. Interpreted seismic section EO_0051 showing the presence of early-rift sediments (W2) eastern of fault F4 and restricted seaward by raised block by fault 2 . 
Structurally, the package is cut by normal faults F1, F2 and F3 as interpreted from the sections most of which are limited on the top by A1 horizon and do not propagate/penetrate further. Faults F1 and F2 indicate possible extension reactivation to Unit 2 (Figure 6(b)). The initiation of fault F4 likely started in Unit 1.

\subsection{Structural and Sedimentation Process}

Thick early Cretaceous to present sediments was deposited in the post rift stage between A2 and A7 horizons (Figure 5(b) and Figure 8(a)). The Tertiary sediments are distributed below and above the Middle Eocene unconformity where in the western part has less sediment infill compared to thick sediments in the eastern part. More than $1000 \mathrm{~m}$ thick layer of post Middle Eocene sediments have been deposited between the seabed and the Middle Eocene (A6). The fault F4 has limited control on the distribution of post rift sediments (Figure 8(a)). Other post rift faults F5 and F7 indicate a local control and distribution of sediment deposited after middle Eocene unconformity.

In early post rift phase between horizons A2 and A6, Cretaceous sediments have been deposited in the west and east depocenters (Figure 6(b) and Figure $8(\mathrm{~b})$ ), and separated by Middle Eocene Unconformity. The thickness between these layers reaches up to $3000 \mathrm{~ms}$ in the south direction where two depressions have been interpreted. Uniform sedimentation dominates the area with progressive increase of settling of sediments due to available space.

Variation in thicknesses of the upper Cretaceous to Paleogene sediments deposited between A4 and A5 is identified by the thinner thickness in NW and thickening towards SE with about $700 \mathrm{~m}$ thick column of sediments in the eastern part (Figure $8(\mathrm{c})$ ). Thickness variation of sediments deposited, the wedges and bounded unit across fault F4 separated by horizon A4 may suggest an inversion feature dominating the unit (Figure 6(a) and Figure 8(c)).

The Early Jurassic rift sediments deposited in small isolated depocenters or depression located in the north and northeast and northwest (Figure 6(b) and Figure $8(d)$ ). Rifting stage is controlled by the presence of faults F1 and F2. Between A1 and A2 there is a change in depositional pattern indicated by isolated depocenters during rifting (Figure $8(e)$ ) and the differences can be traced from section interpretations (Figure 5(a), Figure 6(b) and Figure 7). First, Early Jurassic sediments are accumulated in western and eastern parts of Block 5 in early space created by faults F1 and F2 (Figure 8(d) and Figure 8(e)). The second observation is the notable decrease of early-formed accommodation space filled with Jurassic sediments in the eastern part (Figure 8(e)) with depocenter locus shifting from north towards the south filled by Later Jurassic syn-rift sediments (Figure 8(e)).

\section{Discussion}

\subsection{Block 5 Evolution}

Tectono-sedimentary evolution of Block 5 is the result of sedimentation associated 


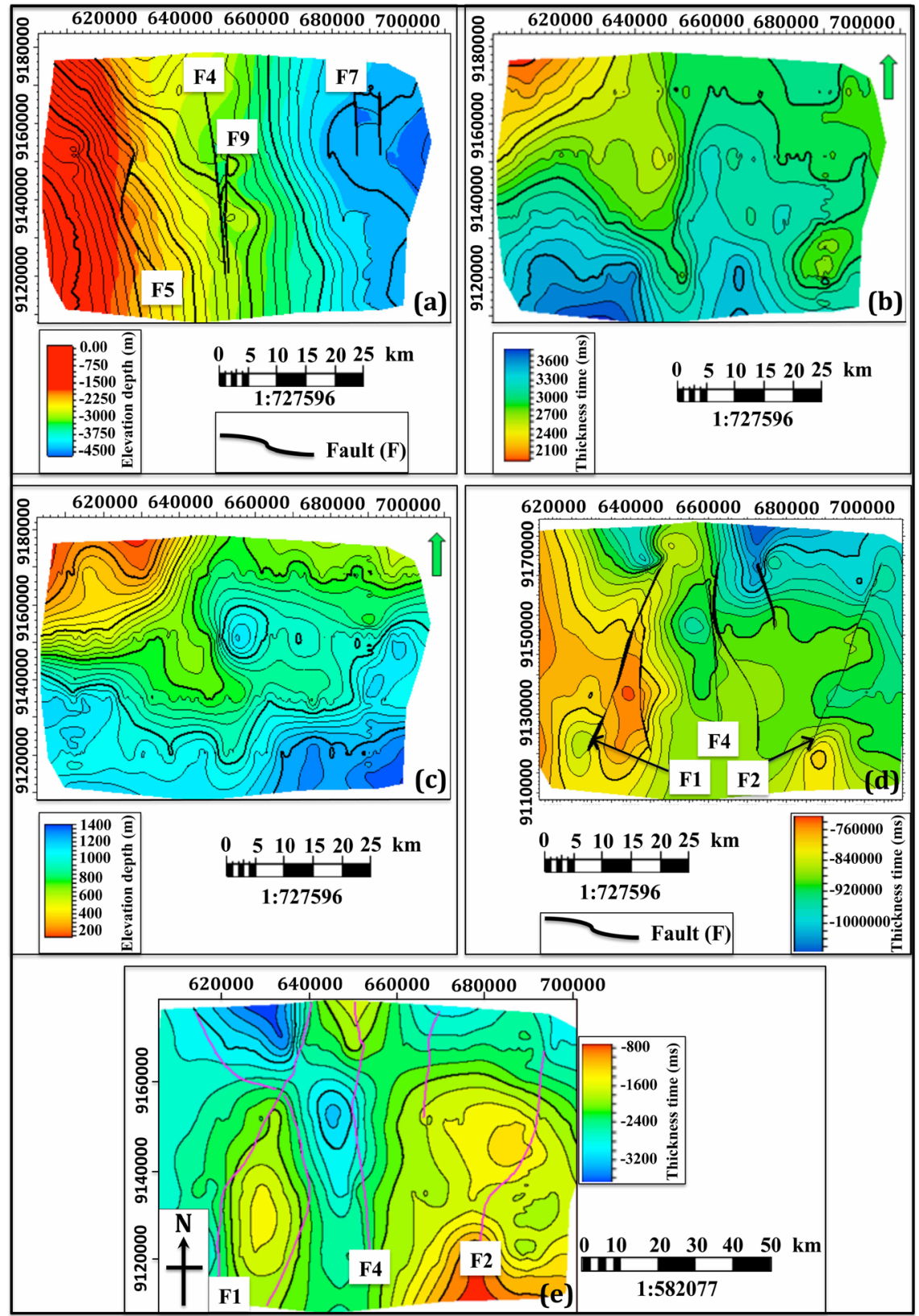

Figure 8. (a) Post-rift structural map of horizon A6 with reactivated fault F4 with reference to horizon A6; (b) Time thickness map between A2 and A6 showing two depressions during the Post Rift phase located to the south; (c) Thickness map showing NW-SE variation indicating lateral change of the sediments deposited during Post Rift between reflector A4 and A5; (d) Time structural map of horizon A1 overlaid with Fault 4 and early rift fault F1 and F2; (e) Time thickness map between A1 and A2 showing N-S and NW-SE trend isolated depocenters during rifting phase.

with major tectonic events since Mesozoic. As part of passive continental margin, Block 5 shows two major rift stages. The rifting stage that is defined by Unit 2 (Figure 8(e); Figure 9(a)) and the well-documented post-rift stage with thick sediments deposited due to high thermal subsidence defined by Units 3 and 4 (Figure 8(b) and Figure 9(b)). 


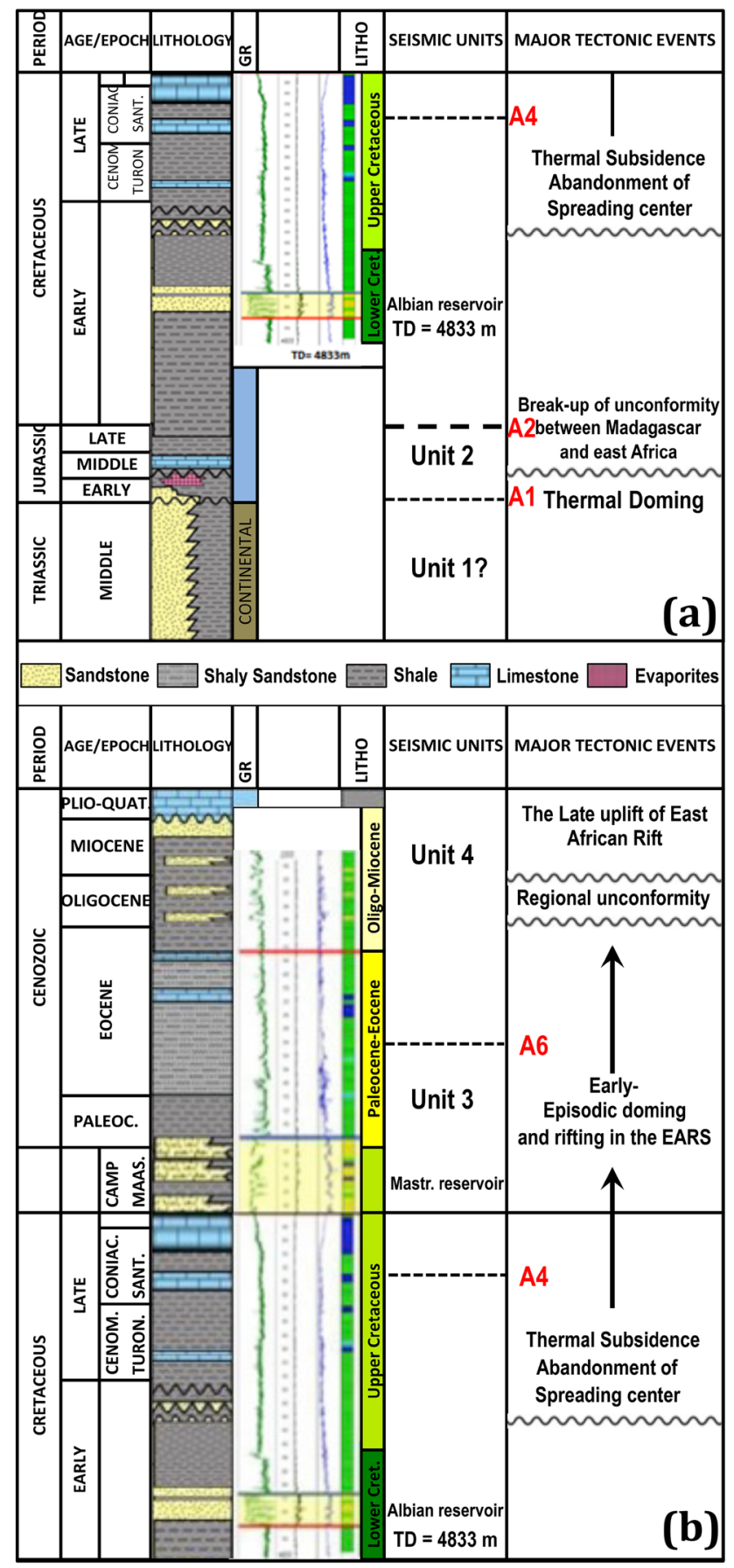

Figure 9. Modified stratigraphy of coastal Tanzania basin showing offshore tectonic events, lithostratigraphy and Seismic units overlaid with Mchongoma-well lithology aiding in correlation of the (a) early rift sedimentation during Mesozoic time in Block 5 (b) post rift sedimentation during Cenozoic to recent. Mchongoma well penetrated up to Albian approximately $4833 \mathrm{~m}$ (modified from [50] and Petrobras, 2013-unpublished report).

The results indicate that during Early Mesozoic, Block 5 was affected by rifting. This event was linked to the continuation of regional Carboniferous to Triassic Karoo rift occurred mostly in the coastal part and extended to offshore 
areas between Triassic to Late Jurassic [1] [2] [14]. The most noted feature associated with this event is the early-rift sediments deposited in small, shallower temporarily depocenters. The associated successive rifting followed the break-up of Gondwana in Middle Jurassic (See Figure 5(a), Figure 8(d), Figure 8(e) and Figure $9(\mathrm{a})$ ) and is bounded by faults F1 and F2.

The early rift faults F1 and F2 in Block 5 (Figure 5(a) and Figure 8(e)) show significant uplifting of the western part towards the east within Block 5. Shallow depressions trending N-S and NW-SE have been interpreted of which shed light to normal early shallow depression. The change of tectonic region during Middle Jurassic would be taken as explanation of the shift of locus of depositional due to structure reactivation. This can be explained by faults with small displacement of which few available were overprinted by sediments and subsequently reshaped by influence of southward drift of Madagascar (Figure 6(b) and Figure $8(\mathrm{e})$ ). The spatial distribution of Jurassic syn-rift sediments was confirmed from this study by variation of wedge W2 created by fault F2 from NW to SE (Figure 5(a) and Figure 7) that is larger in the north (Figure 7 and Figure $8(\mathrm{e})$ ). The result differ slightly from the work by Danforth et al. [40] conducted in the SOBs in which a more developed Early Jurassic syn-rift sedimentation has been recorded and interpreted to be deposited in early half graben. The trend of depression towards the south would also be summed to this and hence confirmation of the presence of graben like feature in the south.

The Jurassic rifting is linked to the uplift of horizon A1 and therefore, the same regional rifting event also occurred in offshore as indicated by correlation of horizon A1. The uplifted horizon A1 (See Figure 5(a) and Figure 8(e)) is linked to its onshore counterpart in which uplift and erosion of the early rift shoulders took place [41]. For offshore, this rift leads to the opening of the ocean in which Block 5 currently sits [2].

In the period between Late Jurassic to Oligocene Block 5 evolved as a slow subsiding passive margin filled with thick post rift sediments extending laterally towards the southeast (See Figure 8(a) and Figure 9(b)). The change from parallel reflection to uniform reflectors between horizons A2 and A6 would further signify the presence of a deep-water environment. More passive sedimentation developed after depositional of Paleogene sediments. From seismic and well data it is clear that the block sits on the wide infill of marine sediment with intercalation of sand and carbonate in which a shallow to deep marine environment is inferred.

\subsection{Structural Style}

The block shows deformation associated with rifting and strike-slip movement. The most prominent structure in Block 5 is the fault F4 that is responsible for two structural styles. The onset of F4 is dated back to the regional southward movement of Madagascar following the separation of Madagascar from Tanzania during Jurassic to Cretaceous. This movement was controlled by remnant transform fault (Davie fracture) in which overprint of N-S structure lineament 
was recorded and named as F4 or Sea gap fault [27] [42]. According to Higgins et al. [42], fault F4 follows the N-S trending magnetic anomaly and crossed by the NE-SW trending Jurassic rift fault. The post-rift sediments are recorded on top of A2. Before deposition of A4 (Lower Coniacian), no fault activity affected the block and all the older faults were dominant. The period was dominated by wide accumulation of fine marine sediments. The later reactivation of F4 and variations of thickness between A6 and A2 horizons (Figure 6(a) and Figure 8(b)) is linked to Late Cretaceous local inversion.

Moreover, the local deformation documented during Late Cretaceous to Middle Eocene (See Figure 6(a)) was the consequence of early reactivation of fault F4 and F9 following the Cretaceous doming. This finding corroborates the documented inversion occurred in onshore and now offshore [1] [16] [40] [43]. The upper part of Unit 3 records this structural inversion as indicated by onset of faults F9.

The second prominent structural style is the strike slip features indicated by a negative flower structure (Figure 5(a) and Figure 8(a)). It is noted that during the Middle Eocene, in which A6 was deposited, fault F4 was reactivated to have the present shape. The reactivation of fault F4 was influenced by the formation of the East Africa Rift [22] [42] [44]. Macgregor [22] defined two rifts occurring during Oligocene to Early Miocene and Late Miocene to Recent. The later is further supported by the deformation of the seabed following the Late Miocene tectonic change inducing transpressive strike-slip responsible for compression features seen today [21] [43] [45].

\subsection{Structural Control of Hydrocarbon System}

The study also identified three elements for the hydrocarbon generation and accumulation in Block 5 (Source, reservoir and traps) as controlled by structures present.

\subsubsection{Source Rock}

Combining core information and seismic section interpretation results in this study indicate the presence of Jurassic rift sediments (W1 and W2), which would be taken as probable early source rock since none of the offshore wells has been drilled to intersect the most known Jurassic and Early Cretaceous source rocks [7] [46]. Furthermore, through placement of these syn-rift sediments as probable source rock in Block 5 is not enough to conclude, as there are no well data to support. From onshore literature, it is well predicted that in offshore the Karoo and Early Jurassic sediments are possibly deeply buried [1]. Therefore in comparison with the result, the finding would be related to $\mathrm{W} 1$ and $\mathrm{W} 2$ in Block 5 or the early N-S and NW-SE depocenters filled with enough organic rich sediments to generate the hydrocarbon.

The normal rift faults are limited in this study, which could further qualitatively define the presence of the early deep depocenters responsible for half graben geometry (Figure 10). The presence of early rift fault has been documented 


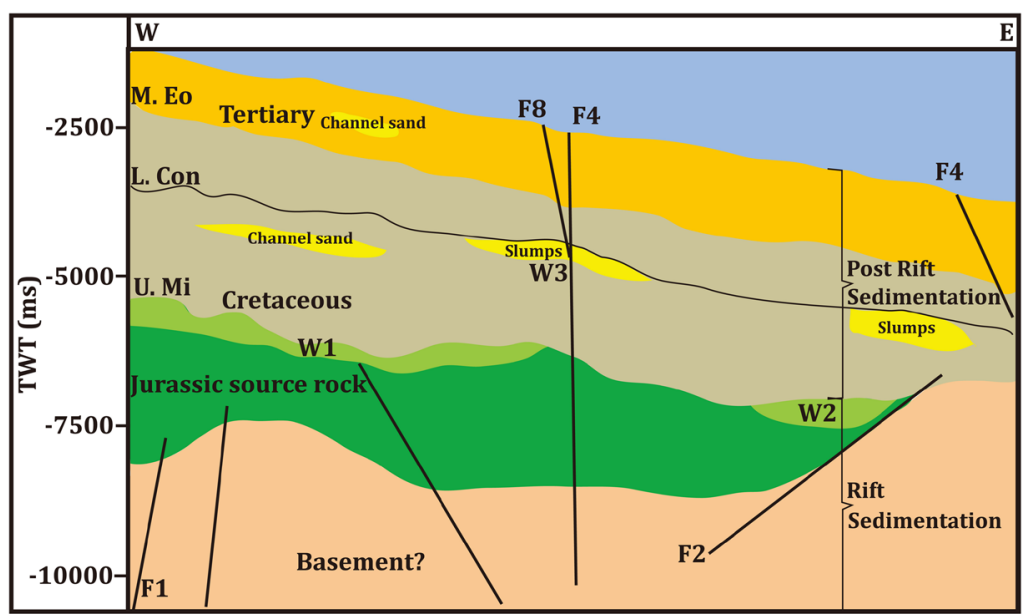

Figure 10. Ideal model showing the possible petroleum system present in the study area.

in Mafia Island and in the SOBs respectively [1] [40] and is postulated to early half graben structure filled with Jurassic sediments of lacustrine and marine. Early Jurassic source rock has been identified to be deposited in the half grabens containing TOC ranging from $0.3 \%-10 \%$ with kerogen type I-III [7].

The second possible source rock is the Early and Late Cretaceous deep marine represented by parallel reflections (Figures 6(a)-(c)), which are referred to post rift sediments. For example from core and cutting sample in the study area, the Late Cretaceous to Eocene shale has less than one percent $(<1 \%)$ Total Organic Carbon (TOC), high oxygen hydrogen ratio and fall under a gas prone kerogen type III gas (Petrobras, 2013-unpublished report). This would mean that transformation of the kerogen took place or less organic matter was deposited and preserved. In comparison to onshore Companian source rock has TOC ranges from $1 \%-12 \%$ [7]. Therefore, due to literature available and results in this study it is proposed that most of the NOBs will be charged with gas either from early oil or gas from young kerogen type III and sedimentation is controlled by tectonic and depositional processes.

\subsubsection{Reservoir Rock}

Block 5 is endowed with world-class reservoir rocks, which host hydrocarbon in other exploited basins occurring in the shelf and slope part of the margin [2] [42] [47]. There is a good correlation between the NOBs and SOBs reservoirs as most of the potential reservoirs are hosted by channel and turbidites (Petrobras, 2013-unpublished report). The sand channels are widely distributed through the post rift phase in Block 5 (Figure 6(c)). The slumps and channel features confirm to the reservoir current available. In the SOBs, reservoirs are Tertiary turbidites and Cretaceous channels sands. The same channels have yielded positive results in the well drilled onshore (Mnazi bay and Songo Songo) [48].

\subsubsection{Trap and Seal}

The most trapping configurations in Block 5 are stratigraphic traps with less structural strap (Figure 6(b), Figure 10 and Figure 11). The syn-depositional 


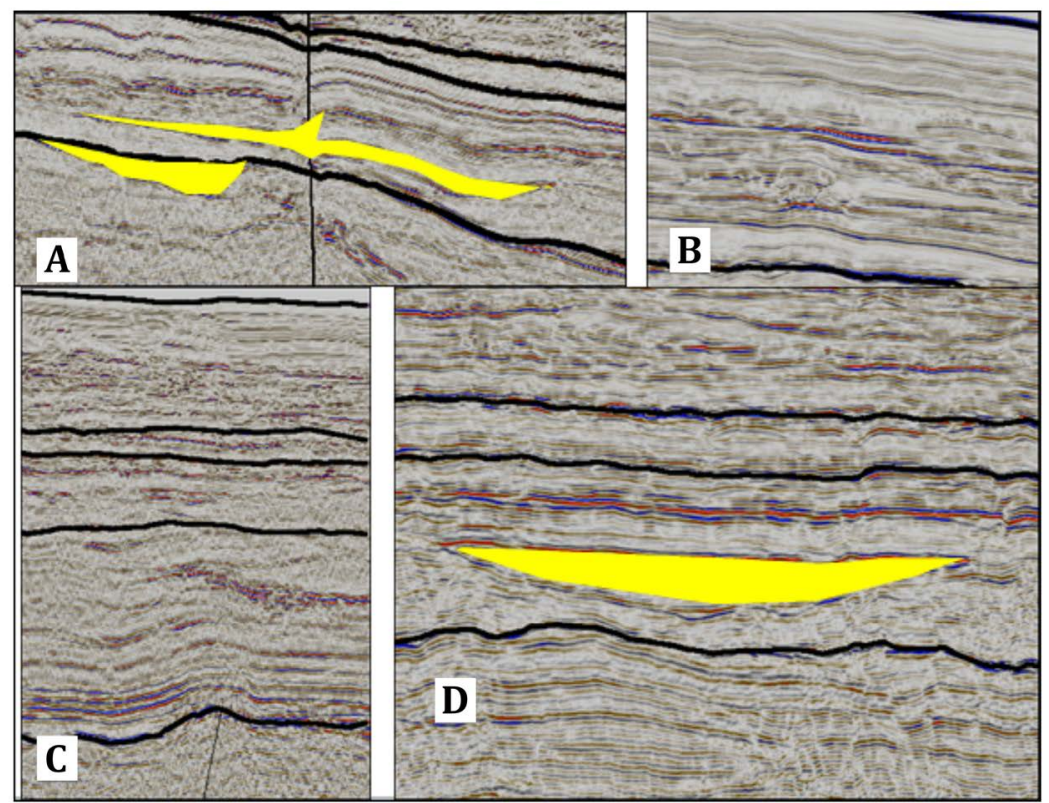

Figure 11. Different trapping and sealing present in Block 5 revealed from seismic section interpretation. The letters A, B and D indicate Post rift stratigraphic traps while C indicates a stratigraphic and structural trap.

anticlines are interpreted to be the best places for trapping since are covered by regional hemipelagic shale [2]. Middle Eocene shale provides a good region seal for late Cretaceous to Paleocene reservoirs [7]. Trapping along the fault F4 is limited as the sealing potential is reduced by the reactivation of this fault, which might form possible conduit for migration of generated hydrocarbon from Jurassic to later reservoirs (Figure 10). Therefore fault F4 can be a positive or negative conduit for the generated hydrocarbon.

\section{Conclusions}

The interpretation of 2D seismic reflection integrated by well data in line with the knowledge of geological setting of Tanzanian margin has revealed four tectonic units representing different tectonic phases and styles occurred in Block 5. The structural style in Block 5 consists of combination of early rift, later inversion and strike slip whose association reflects the same local tectonic setting. The dominant control of sedimentation is explained by the presence of faults F1 and F2, which were later reshaped by strike slip fault F4 that evolved from the basement. Normal early rift and post rift faults from Jurassic to Recent have been suggested to have a local control on sedimentation in Block 5 [1]. Thick sedimentation prevails during the post rift between A2 (Cretaceous) and A6 (Tertiary) and is associated with huge sediments deposited in slow subsiding towards eastern part of Block 5 .

The tectonic in seismic Unit 3 is characterized by thick fine to medium sediments reflecting more deep-water environment. The regressive wedges and sand pinch out or channel sand are regarded as potential reservoir. The Cretaceous to 
Recent channels sands are the most identified reservoirs. The trapping configuration is based on purely stratigraphic as indicated by the presence of dominant sedimentation with limited structural trap since the block was less faulted during Cretaceous to Recent while the wide deposition of the hemipelagic shale provided sealing throughout the block.

There is a clear indication of a more complete petroleum system towards the south as shown in the interpreted sections. Towards the north a less petroleum control is observed while towards the south the clear geometry of the major fault and sediments would be potential control for hydrocarbon generation and migration. The results further show that Block 5 evolved following the Late Jurassic rift, Cretaceous inversion and post Eocene strike slip structural styles, which occurred following the major tectonic events. This reveals that hydrocarbon control in Block 5 is the function of the interplay between tectonics and sedimentation. This finding indicates that structural styles and associated features are potential for hydrocarbon formation and accumulation.

\section{Acknowledgements}

The present research is part of an M.Sc Petroleum project at the Department of Geology, University of Dar es Salaam. This research has been funded by BG Group as part of $\mathrm{K} 2 \mathrm{~K}$ project. We thank Tanzania Petroleum Development Company (TPDC) for providing the data used in this study. We also thank many individuals from the University of Dar es Salaam and TPDC for their assistance in completion of this work. We also thank anonymous reviewers for constructive comments.

\section{References}

[1] Cope, M.J. (2000) Tanzania Mafia Deepwater: Basin Indicates Potential on New Seismic Data. Oil and Gas Journey, 98, 40-49.

[2] Zhixin, W., Zhaoming, W., Chengpeng, S., Zhengjun, H. and Xiaobing, L. (2015) Structural Architecture Differences and Petroleum Exploration of Passive Continental Margin Basins in East Africa. Petroleum Exploration and Development, 42, 733-744. https://doi.org/10.1016/S1876-3804(15)30070-7

[3] Contreras, J., Zühlke, R., Bowman, S. and Bechstädt, T. (2010) Seismic Stratigraphy and Subsidence Analysis of the Southern Brazilian Margin (Campos, Santos and Pelotas Basins. Marine and Petroleum Geology, 27, 1952-1980.

https://doi.org/10.1016/j.marpetgeo.2010.06.007

[4] Mohriak, W.U. and Leroy, S. (2013) Architecture of Rifted Continental Margins and Break-Up Evolution: Insights from the South Atlantic, North Atlantic and Red Sea-Gulf of Aden Conjugate Margins. Geological Society, London, Special Publications, 369, 497-535. https://doi.org/10.1144/SP369.17

[5] Offshore Energy (2013) BG Group Ups Tanzania Gas Reserves Estimates. https://www.offshoreenergytoday.com/bg-group-ups-tanzania-gas-reserves-estimat es/

[6] 2b1st Consulting (2015) Statoil and Exxonmobil Accumulate Discoveries in Block 2. https://www.2b1stconsulting.com/statoil-and-exxonmobil-accumulate-discoveries-i 
n-tanzania-block-2/

[7] Zongying, Z., Ye, T., Shujun, L. and Wenlong, D. (2013) Hydrocarbon Potential in the Key Basins in the East Coast of Africa. Elsevier Science, 40, 582-591.

[8] Maende, A. and Mpanju, F. (2003) Geochemistry and Source Rock Potential of East African Passive Margin. East African Petroleum Conference, Nairobi, 5 March 2003.

[9] Davison, I. and Steel, I. (2018) Geology and Hydrocarbon Potential of the East African Continental Margin: A Review. Petroleum Geoscience, 24, 57.

[10] Rabinowitz, P.D., Coffin, M.F. and Falve, Y.D. (1983) The Separation of Madagascar and Africa. Science, 220, 67-69. https://doi.org/10.1126/science.220.4592.67

[11] Mbede, E.I. (1991) The Sedimentary Basins of Tanzania: Reviewed. Journal of African Earth Sciences and the Middle East, 13, 291-297. https://doi.org/10.1016/0899-5362(91)90092-D

[12] Cox, K. (1992) Karoo Igneous Activity, and the Early Stages of the Break-Up of Gondwanaland. Geological Society, London, Special Publications, 68, 137-148. https://doi.org/10.1144/GSL.SP.1992.068.01.09

[13] Salman, G. and Abdula, I. (1995) Development of the Mozambique and Ruvuma Sedimentary Basins Offshore Mozambique. Sedimentary Geology, 96, 7-41. https://doi.org/10.1016/0037-0738(95)00125-R

[14] Mpanda, S. (1997) Geological Development of the East African Coastal Basin of Tanzania. Stockholm Contributions in Geology, 45, 11-108.

[15] Reeves, C. and De Wit, M. (2000) Making Ends Meet in Gondwana: Retracing the Transforms of the Indian Ocean and Reconnecting Continental Shear Zones. Terra Nova, 12, 272-280. https://doi.org/10.1046/j.1365-3121.2000.00309.x

[16] Nicholas, C.J., Pearson, P.N., McMillan, I.K., Ditchfield, P.W. and Singano, J.M. (2007) Structural Evolution of Southern Coastal Tanzania since the Jurassic. Journal of African Earth Sciences, 48, 273-297. https://doi.org/10.1016/j.jafrearsci.2007.04.003

[17] Kent, P.E., Hunt, J.A. and Johnstone, D.W. (1971) Geology and Geophysics of Coastal Sedimentary Basins of Tanzania. Geophysics Papers, Institute of Geological Sciences, London, 1-101.

[18] Eagles, G. and König, M. (2008) A Model of Plate Kinematics in Gondwana Breakup. Geophysical Journal International, 173, 703-717. https://doi.org/10.1111/j.1365-246X.2008.03753.x

[19] Reeves, C.V. (2016) Gondwana Dispersal Movie CR16ABGE. http://www.reeves.nl/gondwana

[20] Papini, M. and Benvenuti, M. (2008) The Toarcian-Bathonian Succession of the Antisiranana Basin (NW Madagascar): Facies Analysis and Tectonic-Sedimentary History in the Development of the East Africa-Madagascar Conjugate Margins. Journal of African Earth Sciences, 51, 21-38. https://doi.org/10.1016/j.jafrearsci.2007.11.003

[21] Bourget, J., Zaragosi, S., Garlan, T., Gabelotaud, I., Guyomard, P., Dennielou, B. and Schneider, J. (2008) Discovery of a Giant Deep-Sea Valley in the Indian Ocean, off Eastern Africa: The Tanzania Channel. Marine Geology, 255, 179-185. https://doi.org/10.1016/j.margeo.2008.09.002

[22] Macgregor, D. (2015) History of the Development of the East African Rift System: A Series of Interpreted Maps through Time. Journal of African Earth Sciences, 101, 232-252. https://doi.org/10.1016/j.jafrearsci.2014.09.016 
[23] Chattopadhyay, A., Martin, I. and Stearn, J. (2015) Frontier Exploration along East African Continental Margin: Key Challenges for Finding More Oil than Gas. 1st EAGE Eastern Africa Petroleum Geoscience Forum, Dar es Salaam, 17-19 November 2015, 4-8. https://doi.org/10.3997/2214-4609.201414436

[24] Kapilima, S. (2003) Tectonic and Sedimentary Evolution of the Coastal Basin of Tanzania during the Mesozoic Times. Tanzania Journal of Sciences, 29, 1-16.

[25] Iqbal, J., Kidston, A.G., Mliga, N. and Kilembe, E.A. (1996) Petroleum Potential of the Tanzania Coastal Basins: East Africa-A Dynamic Passive Margin. 58th EAGE Conference and Exhibition, 122-123.

[26] Coffin, M.F. and Rabinowitz, P.D. (1987) Reconstruction of Madagascar and Africa: Evidence from the Davie Fracture Zone and Western Somali Basin. Journal of Geophysical Research: Solid Earth, 92, 9385-9406.

https://doi.org/10.1029/JB092iB09p09385

[27] Mahanjane, E.S. (2014) The Davie Fracture Zone and Adjacent Basins in the Offshore Mozambique Margin-A New Insights for the Hydrocarbon Potential. Marine and Petroleum Geology, 57, 561-571. https://doi.org/10.1016/j.marpetgeo.2014.06.015

[28] Mcdonough, K.J., Bouanga, E., Pierard, C., Horn, B., Emmet, P., Gross, J. and Granath, J. (2013) Wheeler-Transformed 2D Seismic Data Yield fan Chronostratigraphy of Offshore Tanzania. The Leading Edge, 32, 162-170. https://doi.org/10.1190/tle32020162.1

[29] Swallow, J.C., Schott, F. and Fieux, M. (1991) Structure and Transport of the East African Coastal Current. Journal of Geophysical Research: Oceans, 96, 22245-22257. https://doi.org/10.1029/91JC01942

[30] Sætre, R. and Da Silva, A.J. (1984) The Circulation of the Mozambique Channel. Deep Sea Research Part A. Oceanographic Research Papers, 31, 485-508. https://doi.org/10.1016/0198-0149(84)90098-0

[31] Veeken, P.C. (2006) Seismic Stratigraphy, Basin Analysis and Reservoir Characterisation. Elsevier, Amsterdam.

[32] Deng, H.W., Guo, J.Y. and Wang, R.J. (2008) Tectono-Sequence Stratigraphic Analysis in Continental Faulted Basins. Earth Science Frontier, 15, 1-7.

https://doi.org/10.1016/S1872-5791(08)60024-X

[33] Prosser, S. (1993) Rift-Related Linked Depositional Systems and Their Seismic Expression. Geological Society Special Publication, 71, 35-66. https://doi.org/10.1144/GSL.SP.1993.071.01.03

[34] Bosence, D.W.J. (1998) Stratigraphic and Sedimentological Model of Rift Basins. In: Purser, B.H. and Bosence, D.W.J., Eds., Sedimentation and Tectonics in Rift Basins. Red Sea-Gulf of Aden, Chapman \& Hall, London, 9-25. https://doi.org/10.1007/978-94-011-4930-3_2

[35] Gawthorpe, R.L. and Leeder, M.R. (2000) Tectono-Sedimentary Evolution of Active Extensional Basins. Basin Research, 12, 195-218. https://doi.org/10.1046/j.1365-2117.2000.00121.x

[36] Morley, C.K. (2002) Evolution of Large Normal Faults: Evidence from Seismic Reflection Data. AAPG Bulletin, 86, 961-978.

[37] Kinabo, B.D., Atekwana, E.A., Hogan, J.P., Modisi, M.P., Wheaton, D.D. and Kampunzu, A.B. (2007) Early Structural Development of the Okavango Rift Zone, NW Botswana. Journal of African Earth Sciences, 48, 125-136.

https://doi.org/10.1016/j.jafrearsci.2007.02.005 
[38] Lindseth, R.O. (1979) Synthetic Sonic Logs-A Process for Stratigraphic Interpretation. Geophysics, 44, 3-26. https://doi.org/10.1190/1.1440922

[39] Onajite, E. (2013) Seismic Data Analysis Techniques in Hydrocarbon Exploration. Elsevier, New York.

[40] Danforth, A., Granath, J., Horn, B. and Komba, K. (2012) Hydrocarbon Potential of the Deep Offshore Tanzania Basin in Context of East Africa's Transform Margin. East Africa: Petroleum Province of the 21 st Century, London, 24-26 October 2012, 32-33.

[41] Said, A., Moder, C., Clark, S. and Abdelmalak, M.M. (2015) Sedimentary Budgets of the Tanzania Coastal Basin and Implications for Uplift History of the East African Rift System. Journal of African Earth Sciences, 111, 288-295. https://doi.org/10.1016/j.jafrearsci.2015.08.012

[42] Higgins, R.I., Oldham, A. and Hood, M. (2012) Exploration of the East Pande Block, Southern Tanzania. East Africa: Petroleum Province of the 21 st Century, London, 24-26 October 2012, 83-84.

[43] Sii, P., Underhill, J. and Jamieson, R. (2015) Role of Structural Inversion along the East African Passive Continental Margin. 1st EAGE Eastern Africa Petroleum Geoscience Forum, Dar es Salaam, 17-19 November 2015, pages.

https://doi.org/10.3997/2214-4609.201414443

[44] Foster, A., Ebinger, C., Mbede, E. and Rex, D. (1997) Tectonic Development of the Northern Tanzanian Sector of the East African Rift System. Journal of the Geological Society, 154, 689-700. https://doi.org/10.1144/gsjgs.154.4.0689

[45] Slind, O.L., Du Toit, S.R. and Kidston, A.G. (1998) The Hydrocarbon Potential of the East Africa Continental Margin. Alconsult International, Calgary, 436-437.

[46] Plummer, P.S., Jospeph, P.R. and Samson, P.J. (1998) Depositional Environments and Oil Potential of Jurassic/Cretaceous Source Rocks within the Seychelles Microcontinent. Marine and Petroleum Geology, 15, 385-401. https://doi.org/10.1016/S0264-8172(98)00019-1

[47] Orsi, M., Alessandrini, A.D., De Sensi, M., Flores, P., Fonnesu, F., Meciani, L. and Moltifiori, G. (2012) The Rovuma Basin (Mozambique, Tanzania) Sixty Years of Exploration: From the Disappointing Initial Results to Recent Supergiant Gas Discoveries. East Africa: Petroleum Province of the 21 st Century, London, 24-26 October 2012, 80-81.

[48] Wentworth Resources Ltd. (2015) Corporate Presentation, October 2015. Wentworth Resources Ltd., Calgary.

https://www.wentworthresources.com/pdf/Wentworth-Corporate-Presentation-Oct ober-2015-FINAL

[49] Teixeira, L., Martinez, V. and Chrispin, S. (2009) Tanzania Utra-Deepwater Exploration. 1-9.

[50] Orca Exploration Group Inc. (2010) Tanzania Exploration and Production. http://www.orcaexploration.com/operations_tanzania_exploration.asp 